\title{
Evaluation of the wound healing properties of South African medicinal plants using zebrafish and in vitro bioassays
}

\author{
Fikile Mhlongo $^{\text {a }}$, Maria Lorena Cordero-Maldonado ${ }^{\mathrm{b}}$, Alexander D. Crawford ${ }^{\mathrm{b}, \mathrm{c}}$, \\ David Katerere $^{\text {a, Maxleene Sandasi }}{ }^{\text {a,e }}$, Anna C. Hattingh ${ }^{\mathrm{d}}$, Trevor C. Koekemoer ${ }^{\mathrm{d}}$, \\ Maryna van de Venter ${ }^{\mathrm{d}}$, Alvaro M. Viljoen ${ }^{\mathrm{a}, \mathrm{e}, \text {, }}$ \\ ${ }^{a}$ Department of Pharmaceutical Sciences, Faculty of Science, Tshwane University of Technology, Private Bag X680, Pretoria, 0001, South Africa \\ ${ }^{\mathrm{b}}$ Luxembourg Centre for Systems Biomedicine, Université du Luxembourg, Belval, Luxembourg \\ ${ }^{\mathrm{c}}$ Department of Preclinical Sciences and Pathology, Norwegian University of Life Sciences (NMBU), Ås, Norway \\ d Department of Biochemistry and Microbiology, Nelson Mandela University, Port Elizabeth, South Africa \\ ${ }^{\text {e } S A M R C ~ H e r b a l ~ D r u g s}$ Research Unit, Tshwane University of Technology, Pretoria, South Africa
}

\section{A R T I C L E I N F O}

\section{Keywords:}

Pro-angiogenesis

Wound healing

Traditional medicine

Zebrafish

Lobostemon fruticosus

Scabiosa columbaria

Cotyledon orbiculato

\begin{abstract}
A B S T R A C T
Ethnopharmacological relevance: In South Africa, medicinal plants have a history of traditional use, with many species used for treating wounds. The scientific basis of such uses remains largely unexplored.

Aim of the study: To screen South African plants used ethnomedicinally for wound healing based on their proangiogenic and wound healing activity, using transgenic zebrafish larvae and cell culture assays.

Materials and methods: South African medicinal plants used for wound healing were chosen according to literature. Dried plant material was extracted using six solvents of varying polarities. Pro-angiogenesis was assessed in vivo by observing morphological changes in sub-intestinal vessels after crude extract treatment of transgenic zebrafish larvae with vasculature-specific expression of a green fluorescent protein. Subsequently, the in vitro anti-inflammatory, fibroblast proliferation and collagen production effects of the plant extracts that were active in the zebrafish angiogenesis assay were investigated using murine macrophage (RAW 264.7) and human fibroblast (MRHF) cell lines.

Results: Fourteen plants were extracted using six different solvents to yield 84 extracts and the non-toxic $(n=72)$ were initially screened for pro-angiogenic activity in the zebrafish assay. Of these plant species, extracts of Lobostemon fruticosus, Scabiosa columbaria and Cotyledon orbiculata exhibited good activity in a concentrationdependent manner. All active extracts showed negligible in vitro toxicity using the MTT assay. Lobostemon fruticosus and Scabiosa columbaria extracts showed noteworthy anti-inflammatory activity in RAW 264.7 macrophages. The acetone extract of Lobostemon fruticosus stimulated the most collagen production at $122 \%$ above control values using the MRHF cell line, while all four of the selected extracts significantly stimulated cellular proliferation in vitro in the MRHF cell line.

Conclusions: The screening of the selected plant species provided valuable preliminary information validating the use of some of the plants in traditional medicine used for wound healing in South Africa. This study is the first to discover through an evidence-based pharmacology approach the wound healing properties of such plant species using the zebrafish as an in vivo model.
\end{abstract}

\section{Introduction}

The skin is the largest single organ by area in the body and forms a protective barrier to the external environment, keeping out bacteria, viruses and maintaining homeostasis in the internal environment
(Percival, 2002). It is estimated that over $\$ 25$ billion is spent each year on the treatment of chronic wounds alone (Dreifke et al., 2015). Wound healing is the restoration of injured skin tissue and is one of the most important therapeutic targets (Kasuya and Tokura, 2014). It involves cell-cell and cell-matrix interactions and proceeds in four distinct but overlapping phases namely; haemostasis (immediate), inflammation

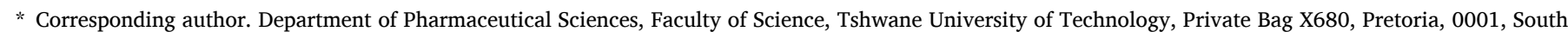
Africa.

E-mail address: viljoenam@tut.ac.za (A.M. Viljoen).
} 


$\begin{array}{ll}\text { Abbreviations: } \\ \text { BrdU } & \text { bromodeoxyuridine } \\ \text { DCM } & \text { dichloromethane } \\ \text { DMSO } & \text { dimethyl sulfoxide } \\ \text { EGFP } & \text { enhanced green fluorescent protein } \\ \text { hpf } & \text { hours post-fertilisation } \\ \text { LPS } & \text { lipopolysaccharides } \\ \text { MRHF } & \text { human dermal tissue fibroblast } \\ \text { MTT } & \text { 3-(4, 5-dimethylthiazol-2-yl)-2, 5-diphenyltetrazolium } \\ & \text { bromide } \\ \text { NO } & \text { nitric oxide } \\ \text { RAW 264.7 cell line murine macrophage from blood } \\ \text { Rg1 } & \text { ginsenoside Rg1 } \\ \text { SIV } & \text { sub-intestinal vessel } \\ \text { Tg } & \text { transgenic line } \\ \text { fli1 } & \text { friend leukemia integration } 1 \text { transcription factor } \\ \text { VEGF } & \text { vascular endothelial growth factor } \\ \text { SCA } & \text { Scabiosa columbaria acetone extract } \\ \text { SCH } & \text { Scabiosa columbaria hexane extract } \\ \text { COE } & \text { Cotyledon orbiculata ethyl acetate extract } \\ \text { LFA } & \text { Lobostemon fruticosus acetone extract }\end{array}$

(0-3 days), cellular proliferation (3-12 days) and remodeling (3-6 months) (Kumar et al., 2007). During wound repair, angiogenesis, a process by which blood vessels grow from existing vessels (Schuermann et al., 2014), is required to supply new tissues with oxygen and nutrients and to dispose the waste products of metabolism (Moon et al., 1999). Angiogenesis is a sub-phase of the proliferative phase which is modulated by a balance of angiogenic factors and inhibitors, and occurs in embryonic development, wound healing and the female reproductive cycle (Fan et al., 2006).

Traditional medicine is an integral part of different South African cultures. An estimated $70 \%$ of the population in South Africa still depend on traditional medicine and up to $60 \%$ of the population consult the estimated 200000 traditional healers in South Africa (Zuma et al., 2016). Over 100 plant species have been identified for traditional topical use in southern Africa, with $41 \%$ of these plants being used to treat wounds (Mabona and Van Vuuren, 2013). South African medicinal plants used for wound healing were identified from the book, Medicinal Plants of South Africa (Van Wyk et al., 1997). Fourteen plant species were selected to validate their traditional application, using in vitro and in vivo models. Table 1 is a list of the selected plants, their traditional uses and the relevant references.

The zebrafish (Danio rerio) is a well-established vertebrate model organism for small-molecule drug discovery (Zon and Peterson, 2005) and biotechnology research (Crawford et al., 2008). It is becoming an increasingly popular model organism for testing the effects of ethnopharmacological treatments, in particular plant-based treatments (Littleton and Hove, 2013). Due to the external fertilization, rapid embryonic development, transparency of embryos and early larval stages, and the low husbandry costs and high fecundity of adults, as well as the amenability to genetic and pharmacological manipulations, zebrafish have become a very popular model for studying organogenesis (Tabassum et al., 2015).

Zebrafish embryogenesis is rapid, with their entire body being established $24 \mathrm{~h}$ post-fertilisation (hpf). Sub-intestinal vessels (SIVs) are developed by $72 \mathrm{hpf}$ and are used to evaluate pro-angiogenic activity. Transgenic zebrafish with endothelial cell-specific expression of green fluorescent protein (GFP) (Lawson and Weinstein, 2002) have become a useful tool to elucidate the molecular and cellular mechanisms of vascular development (Schuermann et al., 2014) and for chemical screening to identify anti-angiogenenic small molecules (Chen et al.,
2018; Huang et al., 2016; Kidd and Weinstein, 2003). These transgenic zebrafish, $\operatorname{Tg}$ (fli-1:EGFP), have also been used for the bioassay-guided fractionation of medicinal plants, enabling both the identification of anti-angiogenic (Bohni et al., 2013; Crawford et al., 2008) and pro-angiogenic (Liu et al., 2011) natural products.

Within this context, the aim of this study was to screen South African plants used ethnomedicinally for wound healing and to assess their potential pro-angiogenic activity using a zebrafish transgenic model. Subsequently, we evaluated the bioactive extracts for their antiinflammatory, cellular proliferation and collagen production properties in cell culture assays.

\section{Materials and methods}

\subsection{Plant material sourcing and extraction}

Plant selection was based on the reported traditional use and availability from the selected location. The plant parts used traditionally were used in this study, the majority of which were leaves. These were collected from the Walter Sisulu Botanical Gardens in Roodepoort, Johannesburg, South Africa or supplied by Parceval (Pty) Ltd (Wellington, South Africa). Taxonomic verification was performed by Mr A Hankey and Prof. AM Viljoen and voucher specimens and retention samples (TUT01 - TUT14) were prepared and stored in the Department of Pharmaceutical Sciences at the Tshwane University of Technology. The plant names were confirmed against the Plant List (http://www.th eplantlist.org) accessed in February 2015.

Plant material was extracted using one of six solvents namely; distilled water, methanol, ethyl acetate, acetone, dichloromethane (DCM) and hexane (purchased from Merck, Germany). Water was purified by a Milli-Q system (Millipore, USA). Ten grams of each plant material were weighed into a conical flask and $100 \mathrm{~mL}$ of solvent added. The conical flask was sealed with foil and placed in a water bath at $45{ }^{\circ} \mathrm{C}$ for $3 \mathrm{~h}$ with shaking at intervals (Sonorex digital $10 \mathrm{P}$, Bendelin Electronic, Berlin, Germany). Following extraction, the extract was vacuum filtered using a Buchner funnel through Whatman (No. 1) filter paper. The extraction process was repeated two more times on the residue to maximize the yield. All the extracts were concentrated under reduced pressure using a vacuum rotary evaporator (Labotech, South Africa).

\subsection{Ethics statement for animal experimentation}

The experiments involving the use of zebrafish were conducted at the Luxembourg Centre for Systems Biomedicine (LCSB). During the animal experimentation, the Zebrafish Facility at the LCSB was registered as an authorised breeder, supplier and user of zebrafish with Grand-Ducal decree of December 10, 2012. All practices involving zebrafish were performed in accordance with European laws, guidelines and policies for animal experimentation, housing and care (European Directive, 2010/ $63 / \mathrm{EU}$ on the protection of animals used for scientific purposes of October 20, 2010 and the Grand-Ducal Regulation of February 11, 2013), and following the principles of the Three Rs - to replace, reduce and refine the use of animals used for scientific purposes. The present study did not involve any procedure within the meaning of Article 3 of the Directive 2010/63/EU and as such it was not subjected to authorization by an ethics committee.

\subsection{Zebrafish husbandry}

Adult Tg (fli1:EGFP) zebrafish, in which endothelial cells express enhanced green fluorescent protein (EGFP), were maintained in the LCSB Aquatic Facility at $28( \pm 0.5){ }^{\circ} \mathrm{C}$ with $14: 10 \mathrm{~h}$ light: dark cycles, respectively, according to standard protocols (Westerfield, 2000). Adult fish were fed with brine shrimps and SDS food twice daily. Embryos were obtained by natural spawning and after collection and sorting, only fertilized eggs were reared in 0.3X Danieau's solution (17 mM NaCl, 2 
Table 1

Selected South African medicinal plants used for wound healing.

\begin{tabular}{|c|c|c|c|c|}
\hline $\begin{array}{l}\text { Species/Common name/ } \\
\text { Vernacular name/(SN) }\end{array}$ & Family & Distribution & Traditional uses & $\begin{array}{l}\text { Plant part } \\
\text { used }\end{array}$ \\
\hline $\begin{array}{l}\text { Aloe arborescens Mill./ } \\
\text { Candelabra aloe/'Inkalane' } \\
\text { (isiZulu) (TUT01) }\end{array}$ & Xanthorrhoeaceae & $\begin{array}{l}\text { Cape Peninsula to Limpopo, Zimbabwe and } \\
\text { Malawi. }\end{array}$ & $\begin{array}{l}\text { Leaves used for burns and wounds. The fresh gel or } \\
\text { processed gel is added as an ingredient of cosmetic } \\
\text { products. A tonic made from the leaves is used in the } \\
\text { treatment or prevention of cancer (Singab et al., 2015; } \\
\text { Van Wyk et al., 1997). }\end{array}$ & Leaves \\
\hline $\begin{array}{l}\text { Bulbine frutescens (L.) Willd./ } \\
\text { Burn jelly plant/'Ibhucu' } \\
\text { (isiZulu) (TUT02) }\end{array}$ & Xanthorrhoeaceae & Popular garden plant found across South Africa. & $\begin{array}{l}\text { The slimy leaves are popular for the treatment of } \\
\text { wounds, burns, rashes, itches, and ringworm, leaf sap } \\
\text { is applied directly to the skin or in form of a warm } \\
\text { poultice (Ghuman and Coopoosamy, 2011; Van Wyk } \\
\text { et al., 1997). }\end{array}$ & Leaves \\
\hline $\begin{array}{l}\text { Bulbine latifolia (L.f.) Spreng./ } \\
\text { 'Ibhucu' (isiZulu) (TUT03) }\end{array}$ & Xanthorrhoeaceae & $\begin{array}{l}\text { Distributed in the eastern and northern parts of } \\
\text { South Africa. }\end{array}$ & $\begin{array}{l}\text { Taken orally in the form of infusions for vomiting and } \\
\text { diarrhoea, to treat convulsions, veneral diseases, } \\
\text { diabetes, rheumatism, and urinary complaints. The } \\
\text { fresh leaf sap is used topically to treat burns, itches } \\
\text { and eczema (Ghuman and Coopoosamy, 2011; Van } \\
\text { Wyk et al., 1997). }\end{array}$ & Leaves \\
\hline $\begin{array}{l}\text { Carpobrotus edulis (L.) N.E.Br./ } \\
\text { Sour fig/'Umgongozi' (isiZulu) } \\
\text { (TUT04) }\end{array}$ & Aizoaceae & $\begin{array}{l}\text { Occurs in sandy areas in the Cape but it is now } \\
\text { commonly grown in many parts of the world. }\end{array}$ & $\begin{array}{l}\text { The leaf juice is gargled to treat infections of the } \\
\text { mouth and throat. Leaf juice is applied to treat } \\
\text { eczema, wounds (Van Wyk et al., 1997; Watt and } \\
\text { Breyer-Brandwijk, 1962). }\end{array}$ & Leaves \\
\hline $\begin{array}{l}\text { Cotyledon orbiculata L./Pigs ear/ } \\
\text { 'Iphewula' (isiXhosa) (TUT05) }\end{array}$ & Crassulaceae & Widely distributed throughout southern Africa. & $\begin{array}{l}\text { The warmed leaf juice is used as drops for earache and } \\
\text { toothache. Poultice applied to wounds, scratches, } \\
\text { sores and ulcers. The juice has been used to treat } \\
\text { epilepsy (Grierson and Afolayan, 1999; Van Wyk } \\
\text { et al., 1997). }\end{array}$ & Leaves \\
\hline $\begin{array}{l}\text { Gunnera perpensa L./River } \\
\text { pumpkin/'Ugobho' (isiZulu) } \\
\text { (TUT06) }\end{array}$ & Gunneraceae & $\begin{array}{l}\text { Wide distribution in the southern, eastern, and } \\
\text { northern parts of South Africa and northwards into } \\
\text { tropical Africa. }\end{array}$ & $\begin{array}{l}\text { To induce or augment labour and as an antenatal } \\
\text { medication to tone the uterus. It may be taken to treat } \\
\text { stomach trouble, rheumatic fever, swellings, } \\
\text { menstrual pain and stomach bleeding or applied } \\
\text { externally for dressing of wounds and for psoriasis ( } \\
\text { Hutchings, 1996). }\end{array}$ & Rhizome \\
\hline $\begin{array}{l}\text { Haemanthus coccineus L./Blood } \\
\text { flower/'Bergajuin' (Afrikaans) } \\
\text { (TUT07) }\end{array}$ & Amaryllidaceae & $\begin{array}{l}\text { Occurring in diverse habitats, mainly coastal scrub } \\
\text { and rocky slopes, throughout the winter rainfall } \\
\text { region of South Africa, from southern Namibia } \\
\text { southwards to the Cape Peninsula and eastwards } \\
\text { to Grahamstown. }\end{array}$ & $\begin{array}{l}\text { Fresh leaves are applied as dressing to septic ulcers, } \\
\text { sores and wounds. Asthma is also treated with this } \\
\text { mixture (Fuchs et al., 2015; Grierson and Afolayan, } \\
\text { 1999; Van Wyk et al., 1997). }\end{array}$ & Leaves \\
\hline $\begin{array}{l}\text { Hypoxis hemerocallidea Fisch., C. } \\
\text { A.Mey. \& Avé-Lall./Star } \\
\text { flower/'Inkomfe' (isiZulu) } \\
\text { (TUT08) }\end{array}$ & Hypoxidaceae & $\begin{array}{l}\text { Widely distributed in the grassland areas of South } \\
\text { Africa. }\end{array}$ & $\begin{array}{l}\text { The leaf is sliced, sap extracted and applied to sores } \\
\text { and burns. Dried leaf is extracted and used as a wash } \\
\text { for wounds (Grierson and Afolayan, 1999; Van Wyk } \\
\text { et al., 1997). }\end{array}$ & Leaves \\
\hline $\begin{array}{l}\text { Lobostemon fruticosus (L.) H. } \\
\text { Buek/Pajama Bush/ } \\
\text { 'Agdaegeneesbos' (Afrikanaans) } \\
\text { (TUT09) }\end{array}$ & Boraginaceae & $\begin{array}{l}\text { Widely distributed in the fynbos region of South } \\
\text { Africa. }\end{array}$ & $\begin{array}{l}\text { Decoctions of the plant are an old Cape remedy for } \\
\text { wounds, skin diseases and ring worms. The fresh } \\
\text { leaves and branch tips are ground to a paste and } \\
\text { applied to wounds. Leaves are also chewed and the } \\
\text { resultant poultice forms a strong elastic layer over the } \\
\text { wound (Van Wyk et al., 1997; Watt and } \\
\text { Breyer-Brandwijk, 1962). }\end{array}$ & Leaves \\
\hline $\begin{array}{l}\text { Melianthus comosus Vahl/Honey } \\
\text { flower/'Ibonya' (isiZulu) } \\
\text { (TUT10) }\end{array}$ & Melianthaceae & $\begin{array}{l}\text { Wide distribution, mainly in the dry interior of } \\
\text { South Africa. }\end{array}$ & $\begin{array}{l}\text { Leaf poultice and leaf decoctions are widely used to } \\
\text { treat septic wounds, sores, bruises, backache, and } \\
\text { rheumatic joints. It is a traditional remedy for snake } \\
\text { bite and to reduce swelling (Hutchings, 1996). }\end{array}$ & Leaves \\
\hline $\begin{array}{l}\text { Mentha longifolia (L.) L./Giant } \\
\text { honey flower/'Ibonya' } \\
\text { (isiZulu) (TUT11) }\end{array}$ & Lamiaceae & $\begin{array}{l}\text { Widely distributed in South Africa and is found in } \\
\text { wet places. }\end{array}$ & $\begin{array}{l}\text { Wild mint is mainly used to treat coughs, colds, } \\
\text { asthma and other respiratory ailments. It is also used } \\
\text { for headache, fever, indigestion, flatulence, hysteria, } \\
\text { painful menstruation, delayed pregnancy and urinary } \\
\text { tract infections. Applied as a poultice to wounds ( } \\
\text { Gulluce et al., (2007); Grierson and Afolayan, (1999); } \\
\text { Van Wyk et al., (1997). }\end{array}$ & Leaves \\
\hline $\begin{array}{l}\text { Melianthus major L./Wild mint/ } \\
\text { 'Inxina' (isiXhosa) (TUT12) }\end{array}$ & Melianthaceae & Occurs only in the Western Cape. & $\begin{array}{l}\text { Leaf poultices and leaf decoctions are widely used to } \\
\text { treat septic wounds, sores, bruises (Van Wyk et al., } \\
\text { 1997). }\end{array}$ & Leaves \\
\hline $\begin{array}{l}\text { Scabiosa columbaria L./Pink } \\
\text { mist/'Makgha' (isiXhosa) } \\
\text { (TUT13) }\end{array}$ & Caprifoliaceae & $\begin{array}{l}\text { Wide distribution in southern Africa and } \\
\text { particularly common in the Western Cape and } \\
\text { grassland areas of the summer rainfall region. }\end{array}$ & $\begin{array}{l}\text { Dried leaves and roots are made into wound healing } \\
\text { ointment (Van Wyk et al., 1997). }\end{array}$ & $\begin{array}{l}\text { Leaves } \\
\text { and roots }\end{array}$ \\
\hline $\begin{array}{l}\text { Xysmalobium undulatum (L.) W.T. } \\
\text { Aiton./Uzara/'Ishongwe' } \\
\text { (isiZulu) (TUT14) }\end{array}$ & Apocynaceae & $\begin{array}{l}\text { Widely distributed in the grassland regions of } \\
\text { South Africa and often found in seasonally wet } \\
\text { places. }\end{array}$ & $\begin{array}{l}\text { Externally, the powdered root is a popular remedy for } \\
\text { sores and wounds. Internally, it is used to treat } \\
\text { diarrhoea, dysentery, and stomach cramps. Also used } \\
\text { for headaches, oedema, and indigestion (Van Wyk } \\
\text { et al., 1997; Watt and Breyer-Brandwijk, 1962) }\end{array}$ & Roots \\
\hline
\end{tabular}


$\mathrm{mM} \mathrm{KCl}, 0.12 \mathrm{mM} \mathrm{MgSO}_{4}, 1.8 \mathrm{mM} \mathrm{Ca}\left(\mathrm{NO}_{3}\right)_{2}, 1.5 \mathrm{mM}$ HEPES $\mathrm{pH} 7.5$ and $1.2 \mu \mathrm{M}$ methylene blue) at $28( \pm 0.5){ }^{\circ} \mathrm{C}$ until needed for the experiments.

\subsection{Determination of maximum tolerated concentrations (MTCs)}

Stock solutions (1 mg/mL) of each extract were prepared in $100 \%$ DMSO. The working solutions were prepared by diluting the stocks with 0.3X Danieau's media to achieve the required concentrations for MTCs $(50,100,250,500$ and $1000 \mu \mathrm{g} / \mathrm{mL})$ and $1 \%$ DMSO in the working solutions. Embryos were collected, sorted to remove debris and unfertilised eggs, and then maintained in $0.3 \mathrm{X}$ Danieau medium at $28^{\circ} \mathrm{C}$ until $16 \mathrm{hpf}$. In 48 plate wells, five embryos were added to each well using a glass pipette and 0.3X Danieau medium was removed and immediately $1 \mathrm{~mL}$ of the test extracts added to six wells in one column at varying concentrations. The control was 0.3X Danieau medium and 1\% DMSO which was always added to the last column wells of the plate. Embryos were incubated at $16 \mathrm{hpf}$ at $28{ }^{\circ} \mathrm{C}$ overnight. Following incubation, the embryos were observed under the microscope to check for signs of toxicity at $48 \mathrm{hpf}$ and $72 \mathrm{hpf}$. Observations were made to check for viability, oedema, cardiovascular defects, dysmorphology, slow development and loss of posture (Maes et al., 2012). The concentrations causing such outcomes were deemed to be too toxic and the maximum tolerated concentration was determined for each extract.

\subsection{Zebrafish larvae angiogenesis assay}

Five embryos at $16 \mathrm{hpf}$ were added to each well in a 48-well plate and $1 \mathrm{~mL}$ of test extract was added at various working concentrations. $20 \mu \mathrm{M}$ of ginsenoside (Rg1) served as a positive control (Zheng et al., 2013) and 1\% DMSO (vehicle) and 0.3X Danieau's were used as negative controls. Embryos were then incubated at $28{ }^{\circ} \mathrm{C}$. At $72 \mathrm{hpf}$, the larvae were anaesthetised with $0.003 \%$ tricaine methanesulfonate (Sigma-Aldrich) and then embedded in 3\% methyl cellulose (Sigma, Germany) for microscopic observation. The morphology of the SIV region in each zebrafish larvae was observed by using a Nikon SMZ25 stereomicroscope. Observation of changes in morphology of blood vessel growth especially the appearance of longer and more spikes sprouting from the SIVs basket was noted as an indication of pro-angiogenesis effect (Zhou et al., 2014). Captured images were analysed using ImageJ 1.38X (NIH, USA).

\subsection{Cell culture assays}

Crude extracts that showed noteworthy pro-angiogenic activity in the zebrafish angiogenesis assay were subjected to in vitro assays to investigate the wound healing properties on different phases of wound healing. RAW 264.7 murine macrophages and MRHF human dermal tissue fibroblast cell lines were purchased from Cellonex, South Africa. All cell culture assays were performed at BioAssaix Screening Services, Nelson Mandela University, Port Elizabeth, South Africa. Both cell lines were maintained in DMEM (RAW 264.7 low-glucose, MRHF highglucose) supplemented with $10 \%$ FBS (HyClone) at $37{ }^{\circ} \mathrm{C}$ in a humidified atmosphere with $5 \% \mathrm{CO}_{2}$. Extracts selected for in vitro testing were: S. columbaria acetone (SCA) and hexane (SCH) extracts, C. orbiculata ethyl acetate (COE) extract and $L$. fruticosus acetone (LFA) extract. The extracts were solubilised in DMSO to a final stock concentration of 100 $\mathrm{mg} / \mathrm{mL}$. Samples were then stored at $4{ }^{\circ} \mathrm{C}$ until required. Stock solutions were diluted to working concentrations in DMEM: 10\% FBS (complete medium).

\subsubsection{In vitro anti-inflammatory assay}

RAW 264.7 cells were seeded in 96-well plates at a density of 25000 cells per well and allowed to attach overnight in a fully humidified incubator at $37{ }^{\circ} \mathrm{C}$. Spent culture media was removed and the samples added to yield final concentrations of 25,50 and $100 \mu \mathrm{g} / \mathrm{mL}$. To assess the anti-inflammatory activity, $50 \mu \mathrm{L}$ of lipopolysaccharide (LPS) containing media was added to a final concentration of $200 \mathrm{ng} / \mathrm{mL}$. Aminoguanidine $(25 \mu \mathrm{M})$, a known inhibitor of iNOS expression served as a positive control. Cells were then incubated for $24 \mathrm{~h}$, allowing time to induce nitric oxide (NO) production. To quantify NO production, $50 \mu \mathrm{L}$ of the spent culture medium was transferred to a new 96-well plate and $50 \mu \mathrm{L}$ Griess reagent added (Saha et al., 2004). Absorbance was measured at $510 \mathrm{~nm}$ using a BioTek Powerwave XS spectrophotometer.

\subsubsection{In vitro cell proliferation assay}

The cell proliferation ELISA assay (Roche) was used to monitor cell proliferation. The MRHF cells were seeded in 96-well culture plates at a density of 5000 cells per well in complete media and left overnight to attach in a fully humidified incubator at $37{ }^{\circ} \mathrm{C}$. All cells except those termed "proliferating cells" were then growth-arrested by replacing their media with serum-free DMEM for $16 \mathrm{~h}$. "Proliferating cells" were again fed with complete media (DMEM: 10\% FBS) for the $16 \mathrm{~h}$ incubation. Media was replaced after $16 \mathrm{~h}$ with $100 \mu \mathrm{L} /$ well fresh DMEM:10\% FBS containing test extracts and incubated for $24 \mathrm{~h}$. Ten microliters BrdU labelling solution (containing final concentration 10 $\mu \mathrm{M}$ BRDU) was added and cells were re-incubated for an additional $24 \mathrm{~h}$ at $37^{\circ} \mathrm{C}$. The labeling media was aspirated and $200 \mu \mathrm{L}$ FixDenat solution was added to fix the cells and denature the DNA, then incubated for 30 min at room temperature. The FixDenat solution was aspirated and 100 $\mu \mathrm{L}$ anti-BrdU-POD (Monoclonal antibody from mouse-mouse hybrid cells (clone BMG 6H8, Fab fragments) conjugated with peroxidase (POD)) working solution was added and cells were incubated for $90 \mathrm{~min}$. The antibody conjugate was removed by washing three times with PBS. Substrate solution containing tetramethyl-benzidine (TMB) was added at $100 \mu \mathrm{L} /$ well and incubated for $30 \mathrm{~min}$ at room temperature. Absorbance was measured at $370 \mathrm{~nm}$ and $492 \mathrm{~nm}$ (reference wavelength) using a BioTek Powerwave XS spectrophotometer.

\subsubsection{In vitro collagen production assay}

The MRHF cells were seeded in 24-well culture plates at a density of 50000 cells per well and left to grow until they reached confluence. The media was replaced with fresh media containing extracts at 25 and 100 $\mu \mathrm{g} / \mathrm{mL}$ and incubated for $48 \mathrm{~h}$. Resveratrol $(10 \mu \mathrm{M})$ and 2-phospho-Lascorbic acid trisodium salt (PLAA, $50 \mu \mathrm{g} / \mathrm{mL}$ ) were used as positive controls. After incubation, spent culture media was removed, cells were washed with PBS and fixed using 95\% ethanol: 5\% acetic acid for $1 \mathrm{~h}$. The fixing solution was removed, and the culture plates were washed by immersion in tap water for $15 \mathrm{~min}$. The plates were air dried before adding $1 \mathrm{~mL}$ of $1 \%$ Sirius Red dye in $\mathrm{H}_{2} \mathrm{O}$ as previously described (Tullberg-Reinert and Jundt, 1999). Cells were stained for $1 \mathrm{~h}$ under mild shaking on a microplate shaker. Thereafter, the dye solution was removed and the stained cell layers extensively washed with $0.01 \mathrm{~N} \mathrm{HCl}$ to remove any unbound dye. Bound dye was dissolved by adding $0.3 \mathrm{~mL}$ of $0.1 \mathrm{~N} \mathrm{NaOH}$ : methanol (1:1) and shaking using a microplate shaker for $30 \mathrm{~min}$ at room temperature. The dye solution was transferred to 96-well plates and the absorbance measured with a BioTek Powerwave XS spectrophotometer at $550 \mathrm{~nm}$. Cell-free wells treated with extracts were run in parallel to compensate for any background staining originating from the extracts.

\subsection{Statistical analysis}

All experiments were performed at least three times, and all values were presented as mean \pm standard deviation of the triplicates. The twotailed student's t-test was used to test for statistically significant differences compared to controls with the in vitro results. The indicator of significance was $p<0.05$. 


\section{Results}

\subsection{Maximum tolerated concentrations}

From the literature, 14 plant species were identified which were easily accessible (Table 1 ). These plants were extracted with different solvents and resulted in a total of 84 extracts. Initially, the maximum tolerated concentration assay was performed on the 84 extracts to determine if any of the extracts were toxic, and to establish the dose at which the pro-angiogenesis assay would be performed. Twelve extracts showed death of the embryos at all concentrations tested and were not investigated further. The remaining 72 extracts were then screened for pro-angiogenesis activity using the Zebrafish model. Detailed results of the preliminary MTC assay are documented in the dissertation of Mhlongo (2017).

\subsection{Zebrafish pro-angiogenesis assay}

For the evaluation of potential pro-angiogenic activity of crude plant extracts, embryos of transgenic fli-1:EGFP zebrafish were used. In this line, EGFP expression is driven by the zebrafish fli-1 promoter, which is expressed in the vascular endothelium, resulting in high expression of EGFP in the embryonic vasculature. This permits direct visualization of the endothelial cells of the vessel wall (Weinstein, 2002). In the zebrafish life cycle, by $72 \mathrm{hpf}$ the SIVs show a clear pattern which can aid in visualization of any ectopic vessels in the SIVs, indicating pro-angiogenesis.

Broad screening of the 72 plant extracts for pro-angiogenic activity revealed that majority of the plant species were not active for proangiogenesis. The extracts of $A$. arborescens, B. frutescens, B. latifolia, C. edulis, G. perpensa, H. coccineus, H. hemerocallidea, M. comosus and M. major did not display pro-angiogenic activity in the SIVs as there was no appearance of ectopic vessels. Nine representative images of each inactive plant species are presented in the supplementary file (Suppl. Fig. 1). These extracts were therefore not investigated further.

Extracts of three plant species i.e., L. fruticosus (acetone), $S$. columbaria (acetone and hexane) and $C$. orbiculata (ethyl acetate) were found to be potentially active and were further assessed for dose response effects. As the MTC values differed between the extracts, the following concentration ranges were assessed for each extract: acetone extract of L. fruticosus (LFA - 50, 75, 100, $150 \mu \mathrm{g} / \mathrm{mL}$ ), acetone extract of S. columbaria (SCA - 150, 200, 250, $300 \mu \mathrm{g} / \mathrm{mL}$ ), hexane extract of S. columbaria (SCH - 300, 400, 500, $600 \mu \mathrm{g} / \mathrm{mL}$ ) and the ethyl acetate extract of $C$. orbiculata (COE - 300, 400, 500, $600 \mu \mathrm{g} / \mathrm{mL}$ ).

Fig. 1 shows the results after treatment with different concentrations of the active crude extracts. There was no pro-angiogenic effect following treatment with the negative control (0.3X Danieau medium) (Fig. 1a), or the vehicle control (1\% DMSO). To validate the zebrafish pro-angiogenesis assay, $20 \mu \mathrm{M}$ of ginsenoside $\mathrm{Rg} 1$, a panaxatriol saponin isolated from Panax notoginseng with previously reported pro-angiogenic activity (Zheng et al., 2013) served as a positive control (Fig. 1b), in which evidence of a pro-angiogenic phenotype was observed in the SIVs of $72 \mathrm{hpf}$ zebrafish larvae, by appearance of longer and more sprouts. In the case of the crude extracts, L. fruticosus (LFA, $100 \mu \mathrm{g} / \mathrm{mL}$, Fig. 1c), S. columbaria (SCA, $250 \mu \mathrm{g} / \mathrm{mL}$, Fig. 1d), S. columbaria (SCH, $500 \mu \mathrm{g} / \mathrm{mL}$, Fig. 1e) and C. orbiculata (COE, $500 \mu \mathrm{g} / \mathrm{mL}$, Fig. 1f) displayed the best
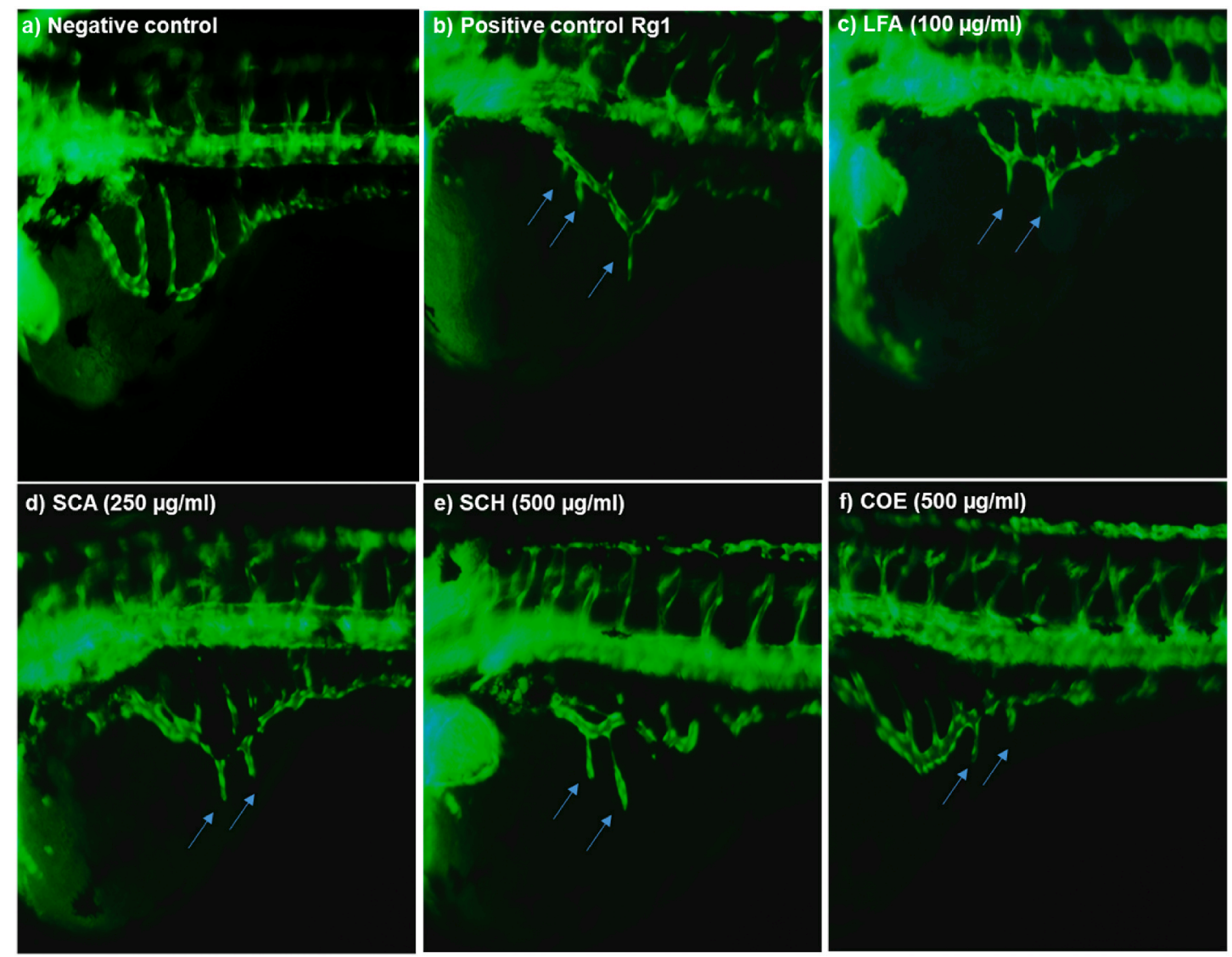

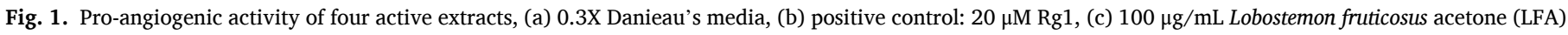

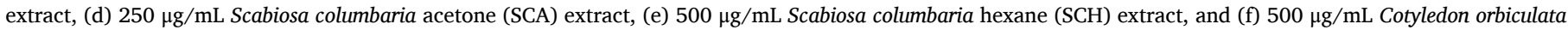

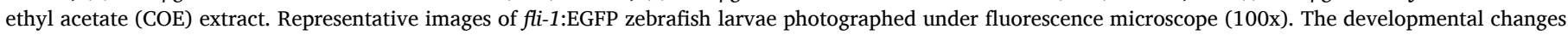

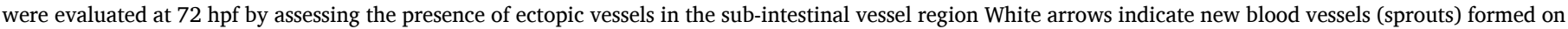
the SIVs. 
pro-angiogenic activity at the indicated concentrations. These four potentially pro-angiogenic extracts were then further tested in the secondary in vitro bioassays.

\subsection{In vitro anti-inflammatory assay}

Acetone extracts of $L$. fruticosus (LFA), hexane and acetone extracts of S. columabria (SCH and SCA) and ethyl acetate extracts of $C$. orbiculata (COE) were tested for anti-inflammatory activity on the RAW 264.7 cell line at 25, 50 and $100 \mu \mathrm{g} / \mathrm{mL}$ (Fig. 2). For LFA, a dose-response relationship was observed. Increasing the concentration of the extract was accompanied by increased inhibition of NO production indicating antiinflammatory activity. The nitrite concentration decreased from 15.3 $\mu \mathrm{M}$ to $10.8 \mu \mathrm{M}$ when the LFA concentration was increased from $25 \mu \mathrm{g} /$ $\mathrm{mL}$ to $100 \mu \mathrm{g} / \mathrm{mL}$. The SCH and SCA extracts were only active at the highest test concentrations, while COE showed no significant antiinflammatory activity.

\subsection{In vitro cellular proliferation assay}

The LFA, SCA, SCH and COE extracts were tested at $25 \mu \mathrm{g} / \mathrm{mL}$ and $100 \mu \mathrm{g} / \mathrm{mL}$ for cell proliferation activity using MRHF human skin fibroblasts (Table 2). All extracts showed increased BrdU incorporation ranging from $35 \%$ to $50 \%$ (i.e. $7 \%-22 \%$ higher than arrested cells) at the lowest concentrations while all except SCA showed 15\%-32\% higher proliferation compared to the control at $100 \mu \mathrm{g} / \mathrm{mL}$. SCA showed apparent cell inhibition at the highest concentration and COE showed no difference in proliferative effects between the two concentrations.

\subsection{In vitro collagen production assay}

Collagen synthesis in MRHF cells was significantly increased at both concentrations ( 25 and $100 \mu \mathrm{g} / \mathrm{mL}$ ) for LFA as shown in Fig. 3. The 25 $\mu \mathrm{g} / \mathrm{mL}$ concentration stimulated collagen production most at $122 \%$ higher than the control and the $100 \mu \mathrm{g} / \mathrm{mL}$ concentration stimulated $72 \%$ higher than control. The acetone and hexane extracts of $S$. columbaria also increased collagen synthesis significantly, with increases ranging between 6 and 19\% higher than control cells.

\section{Discussion}

Over 100 plant species have been identified for traditional topical
Table 2

Effects of Lobostemon fruticosus acetone extract, Scabiosa columbaria hexane and acetone extracts and Cotyledon orbiculata ethyl acetate extract on cellular proliferation. Data are presented as mean $\pm \mathrm{SD}$ of three individual experiments.

\begin{tabular}{lllll}
\hline \multicolumn{5}{l}{$\%$ BrdU incorporated } \\
\cline { 2 - 5 } & LFA & SCH & SCA & COE \\
\hline $\begin{array}{l}\text { Proliferating cells } \\
\text { Growth arrested }\end{array}$ & $100 \pm 27.6$ & $100 \pm 27.6$ & $100 \pm 27.6$ & $100 \pm 27.6$ \\
$\quad$ cells & $28.2 \pm 8.6$ & $28.2 \pm 8.6$ & $28.2 \pm 8.6$ & $28.2 \pm 8.6$ \\
$25 \mu \mathrm{g} / \mathrm{mL}$ & $35.8 \pm 4.0$ & $49.3 \pm 12.1^{*}$ & $49.8 \pm$ & $48.2 \pm$ \\
& & & $6.5^{* *}$ & $9.8^{*}$ \\
$100 \mu \mathrm{g} / \mathrm{mL}$ & $52.0 \pm$ & $60.7 \pm$ & $14.2 \pm 4.7$ & $43.2 \pm$ \\
& $6.9^{* *}$ & $12.8^{* *}$ & & 12.8 \\
\hline
\end{tabular}

${ }^{*} p<0.05 ;{ }^{* *} p<0.01$ compared to growth arrested cells.

use in southern Africa, with $41 \%$ of these plants being used to treat wounds (Mabona and Van Vuuren, 2013). The scientific basis of such uses remains largely unexplored. As the basis for our survey, we selected 14 South African medicinal plants with reported uses by traditional healers for wound healing (Van Wyk et al., 1997). Effective plant remedies might contribute to wound healing by acting in one or more of the wound healing phases, which encompass hemostasis, inflammation, proliferation and remodeling (Liu et al., 2011). Angiogenesis, the growth of new blood vessels, is a key process of the proliferative stage of wound healing. Therefore, we first used a zebrafish-based angiogenesis assay to screen the 84 extracts from the 14 plant species for potential pro-angiogenic activity. Crude extracts with pro-angiogenic activity in this zebrafish-based screen were further evaluated for additional bioactivities relevant to the inflammation and remodeling phases of wound healing, using in vitro methods.

In this study, we found that the acetone extract of $L$. fruticosus was the most active, inducing angiogenesis in zebrafish at $100 \mu \mathrm{g} / \mathrm{mL}$ compared to the acetone extract of $S$. columbaria $(250 \mu \mathrm{g} / \mathrm{mL})$, hexane extract of $S$. columbaria $(500 \mu \mathrm{g} / \mathrm{mL})$ and ethyl acetate extract of C. orbiculata $(500 \mu \mathrm{g} / \mathrm{mL})$. The mode by which these extracts effect their actions was not explored. However, the molecular and cellular mechanisms of angiogenesis are well-characterized, and involve proangiogenic factors such as vascular endothelial growth factor (VEGF) and their signalling pathways. For example, Radix rehmanniae extracts have been reported to increase VEGF expression for improved angiogenesis, resulting in the promotion of wound healing (Liu et al., 2014). It is possible, therefore, that active constituents in the pro-angiogenic

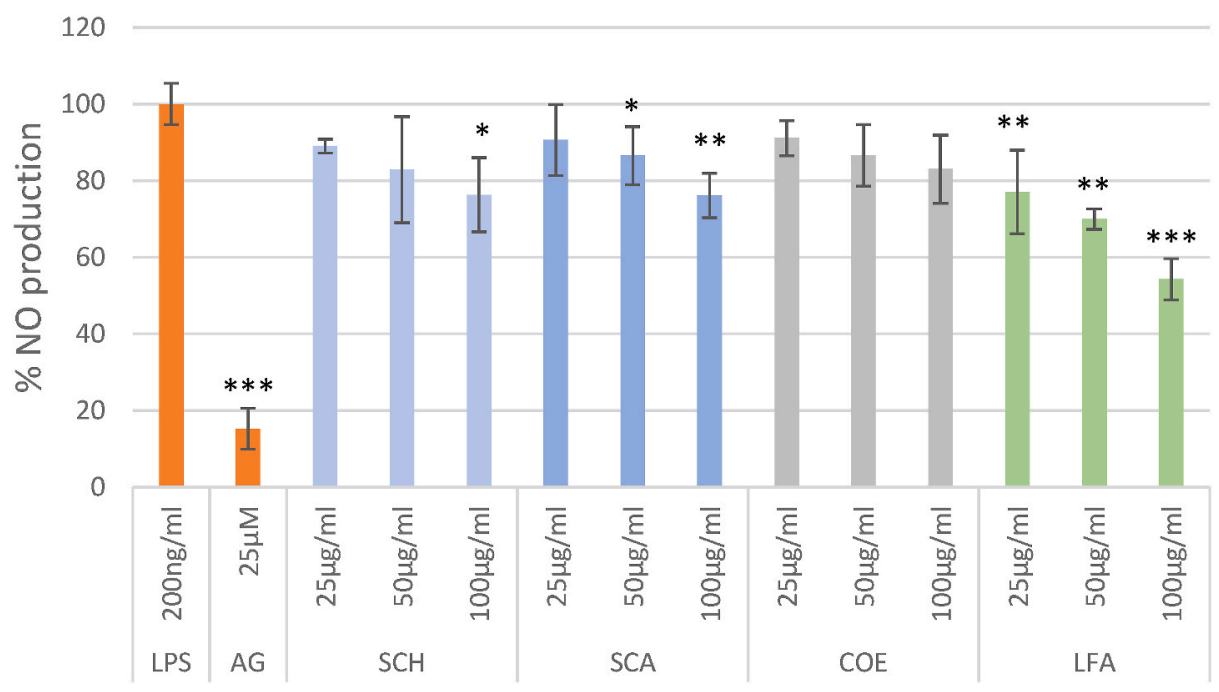

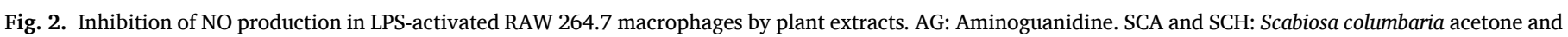

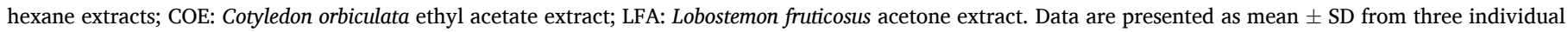
experiments. ${ }^{*} p<0.05$; ${ }^{* *} p<0.01 ; * * * p<0.001$ compared to LPS activated control. 


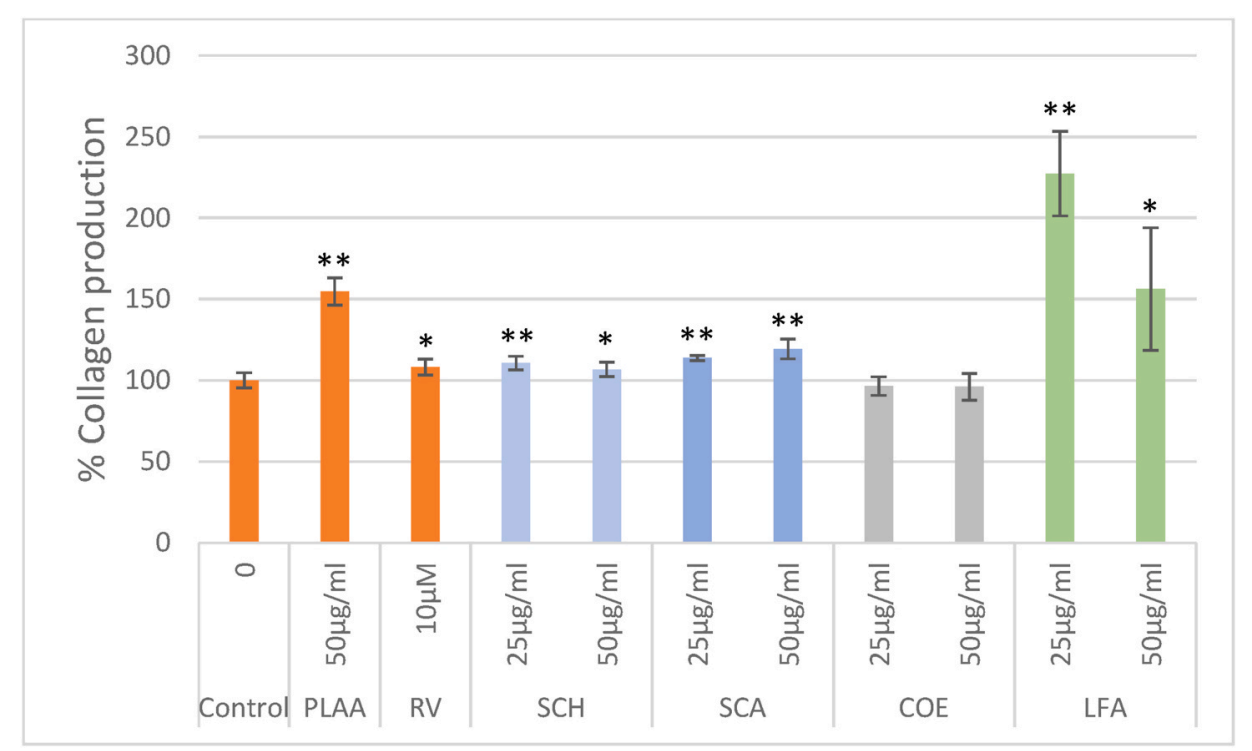

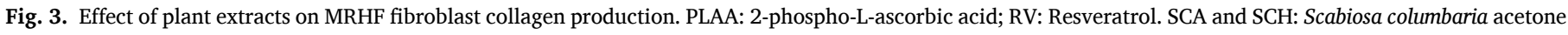

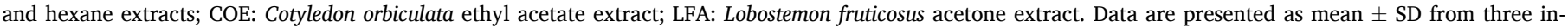
dividual experiments. ${ }^{*} p<0.05$; ${ }^{* *} p<0.001$ compared to control.

extracts we report here could act by (1) upregulating expression of VEGF or other pro-angiogenic factors, (2) targeting intracellular components of these signalling pathways, or (3) binding directly to these receptors on endothelial cells, thereby inducing proliferation and migration of endothelial cells and increasing angiogenic vessel formation.

In pro-angiogenic activity studies, plant extracts have been generally tested for their influence on the formation of blood vessels in vivo, with special attention to the impact on VEGF expression (Kasote et al., 2015). VEGF-A is the most potent pro-angiogenic protein described to date and it induces proliferation, sprouting and tube formation of endothelial cells. We further explored the effects of the extracts which had been found to be promising in the zebrafish model using cultured macrophages and skin fibroblasts in an attempt to understand their effects on individual phases of wound healing. Cell culture assays were used to investigate effects of active extracts on NO production (anti-inflammatory assay), cellular proliferation (BrdU assay) and collagen production (Sirius red assay).

When a wound occurs, it is accompanied within a short time by pain, reddening and oedema of tissue (Houghton et al., 2005). These are all symptoms of inflammation. Lipopolysaccharide (LPS) acts as a prototypical endotoxin by binding to the receptors of the cell types such as monocytes, macrophages and B-cells which promotes secretion of pro-inflammation cytokines, production of $\mathrm{NO}$ and eicosanoids (Heumann and Roger, 2002). Over production of NO induces tissue damage associated with acute and chronic inflammation. Plants are considered to be a good source of natural anti-oxidant molecules (Katalinic et al., 2006) and therefore inhibit NO production. The L. fruticosus acetone extract, $S$. columbaria hexane extract and $S$. columbaria acetone extract appear to reduce NO production to some extent therefore confirming that there is potential for these extracts to have anti-inflammatory effects. Of those, the LFA was shown to be the most potent of the three extracts. Similarly, a previous study revealed that the hot water extract of Ulmus pumila stem bark significantly decreased nitrite accumulation in LPS-stimulated RAW 264.7 cells (Joo et al., 2014). Another study revealed that extracts of Malus sieboldii, Vaccinium oldhamii, Corylus hallaisanensis, Carpinus laxiflora, Styrax obassia, and Securinega suffruticosa showed potent NO inhibition (above 70\%) at a concentration of $100 \mu \mathrm{g} / \mathrm{mL}$, demonstrating that some extracts, and including the ones reported in this study, may be promising candidates in preventing inflammatory diseases mediated by excessive production of NO (Yang et al., 2009).
Fibroblasts secrete growth factors that stimulate cellular proliferation (Houghton et al., 2005). An extract which stimulates the growth of fibroblasts can therefore be thought to assist in wound healing. In a previous study, low, but not statistically significant stimulation of growth was observed with low doses of Buddleja globosa leaf aqueous extract (Mensah et al., 2001). Generally during wound healing, cellular proliferation, cell number and DNA synthesis increase (Stadelmann et al., 1998). The BrdU assay demonstrated statistically significant increase in proliferation of growth-arrested MRHF fibroblasts at one or both concentrations for all the extracts compared to the untreated growth-arrested control cells. This was expected based on the ability of the four extracts to be pro-angiogenic in the angiogenesis assay since angiogenesis is a sub-phase of proliferative phase of wound healing.

Fibroblasts are responsible for the production of most of the collagen in the remodeling phase (Metcalfe and Ferguson, 2007). Staining of collagens by Sirius Red, a standard histological procedure, was applied to quantify collagen synthesis in MRHF cell cultures in situ (Tullberg-Reinert and Jundt, 1999). The LFA, SCH, SCA and COE extracts were tested for collagen production to identify if these extracts could aid in speeding up the remodeling of granulation tissue. All the extracts except COE demonstrated an increase in collagen production relative to the controls. The $25 \mu \mathrm{g} / \mathrm{mL}$ of the acetone extract for $L$. fruticosus stimulated the most collagen production at $122 \%$ higher than the control. In a previous study it was indicated that Aloe vera extract treatment of wounds in diabetic rats enhanced the process of wound healing by influencing collagen synthesis and maturation, and wound contraction (Chithra et al., 1998). This further confirms that the plant extracts in this study can be potential collagen production agents.

Although the three active species are widely used in traditional healing, the chemistry remains largely unexplored. Phenolic acids derived from hydroxybenzoic acid (gallic acid, 4-OH benzoic acid, 4-OH benzaldehyde), hydroxycinnamic acid (chlorogenic acid, caffeic acid) and a flavan-3-ol (catechin), have been identified in the methanol leaf extract of S. columbaria (Akar, 2021). Although one needs to be cautious to extrapolate from these studies, it remains interesting to note that wound healing properties have been ascribed to these phenolics (Chingwaru et al., 2019). Gallic acid induced wound healing potential through anti-oxidant capacity, acceleration of cell migration of human keratinocytes and fibroblasts in both normal and hyperglucidic conditions. Furthermore, focal adhesion kinase (FAK), c-Jun N-terminal kinase (JNK) and extracellular signal-regulated kinase (Erk) were 
activated (Yang et al., 2016). Catechin has been shown to induce cell migration, accelerate wound closure and increase fibroblast migration. Chlorogenic acid elicited keratinocyte wound closure, induced fibroblast migration and enhanced angiogenesis through capillary-like tube formation of endothelial cells in vitro (Moghadam et al., 2017). Caffeic acid displayed anti-inflammatory and wound healing activities in skin-incised mice (Song et al., 2008).

Bufadienolide glycosides, orbicusides A-C, and tyledoside C, are cardiac glycosides that have been identified as the toxic principles of C. orbiculata (Steyn et al., 1999). Although cardiac glycosides are not associated with wound healing they have been shown to exert anti-inflammatory activity (Deng et al., 2020; Jansson et al., 2021).

Using LC-LTQ-Orbitrap mass spectrometry Bedane et al., (2020) identified thirteen compounds (p-hydroxybenzoic acid, lycopsamine-N-oxide, caffeic acid, loliolide, 3- indolcarbaldehyde, globoidnan B, rabdosiin, syringaresinol, pinoresinol, rutin, rosmarinic acid, keampferol-3-O-rutinoside and globoidnan $\mathrm{A}$ in the aerial parts of L. fruticosus. Rosmarinic acid, a hydroxycinnamic acid derivative displayed topical wound healing activity in a rat experimental wound model by reducing wound size (Küba et al., 2021). Rutin, a biflavonoid displayed wound healing activities in hyperglycaemic rats by reducing oxidative stress and inflammatory response (Chen et al., 2020). Pinoresinol is a lignan and displayed wound healing potential by stimulating proliferation and migration of keratinocytes and mouse embryo fibroblasts (Melguizo-Rodríguez et al., 2021). Loliolide, a monoterpenoid hydroxylactone displayed wound healing activities by reducing oxidative stress and enhancing the expression of epidermal growth factor receptor signalling pathway (PI3K, AKT), migration factors, keratinocyte growth factor and inflammatory interleukins IL-1, IL-17, IL-22 during cellular scratching process (Park et al., 2019).

In conclusion, our study has provided a scientific basis for plants used traditionally in wound healing through an evidence-based ethnopharmacological approach. Using in vivo and in vitro assays, we have identified $S$. columbaria, $C$. orbiculata and $L$. fruticosus as being active in promoting the proliferative phase of wound healing through their proangiogenic activity and stimulation of fibroblast proliferation. Scabiosa columbaria and $L$. fruticosus also showed potential in preventing excessive inflammation and promoting the remodeling phase by stimulating fibroblast collagen production.

\section{Declaration of interests}

\The authors declare that they have no known competing financial interests or personal relationships that could have appeared to influence the work reported in this paper.

囚The authors declare the following financial interests/personal relationships which may be considered as potential competing interests:

\section{Funding}

This work was funded by the National Research Foundation [grant number: 86923], South African Medical Research Council [EMU grant number 23015] and the Faculty of Science (Tshwane University of Technology).

\section{CRediT authorship contribution statement}

Fikile Mhlongo: Performed all in vitro and in vivo assays, Formal analysis, and writing of the manuscript, Writing - original draft. Maria Lorena Cordero-Maldonado: Assisted with zebrafish in vivo assays, Writing - original draft. Alexander D. Crawford: Assisted with zebrafish in vivo assays, Writing - original draft. David Katerere: Project administration, Supervision, Writing - review \& editing. Maxleene Sandasi: Assisted with zebrafish in vivo assays, Writing - original draft. Anna C. Hattingh: Assisted with in vitro assays, Writing - original draft. Trevor C. Koekemoer: Assisted with in vitro assays, Writing - original draft. Maryna van de Venter: Assisted with in vitro assays, Writing original draft. Alvaro M. Viljoen: Conceptualization, Supervision.

\section{Declaration of competing interest}

A Viljoen declared his role as the Editor-in-Chief of the Journal of Ethnopharmacology.

\section{Acknowledgments}

The authors thank the members of the formerly Chemical Biology Group at the Luxembourg Centre for System Biomedicine for assisting and training with the zebrafish experiments, and members of Prof M. van de Venter's laboratory (Nelson Mandela University, BioAssaix.com) for assistance and training with the in vitro studies.

\section{Appendix A. Supplementary data}

Supplementary data to this article can be found online at https://doi. org/10.1016/j.jep.2021.114867.

\section{References}

Akar, Z., 2021. Chemical compositions by using LC-MS/MS and GC-MS and antioxidant activities of methanolic extracts from leaf and flower parts of Scabiosa columbaria subsp. columbaria var. columbaria L. Saudi J. Biol. Sci. https://doi.org/10.1016/j. sjbs.2021.07.039.

Bedane, K.G., Zuhlkea, S., Spitellera, M., 2020. Bioactive constituents of Lobostemon fruticosus: anti-inflammatory properties and quantitative analysis of samples from different places in South Africa. South Afr. J. Bot. 131, 174-180. https://doi.org/ 10.1016/j.sajb.2020.02.016.

Bohni, N., Cordero-Maldonado, M.L., Maes, J., Siverio-Mota, D., Marcourt, L., Munck, S., Kamuhabwa, A.R., Moshi, M.J., Esguerra, C.V., de Witte, P.A., Crawford, A.D., Wolfender, J.L., 2013. Integration of microfractionation, qNMR and zebrafish screening for the in vivo bioassay-guided isolation and quantitative bioactivity analysis of natural products. PLoS One 8 (5), e64006. https://doi.org/10.1371/ journal.pone.0064006.

Chen, L.-Y., Huang, C.-N., Liao, C.-K., Chang, H.-M., Kuan, Y.-H., Tseng, T.-J., Yen, K.-J., Yang, K.-L., Lin, H.-C., 2020. Effects of rutin on wound healing in hyperglycemic rat. Antioxidants 9, 1122. https://doi.org/10.3390/antiox9111122s.

Chen, K., Wang, C., Fan, Y., Gu, J., Han, Z., Wang, Y., Gao, L., Zeng, H., 2018. Identification of mundoserone by zebrafish in vivo screening as a natural product with anti-angiogenic activity. Exp. Ther. Med. 16, 4562-4568. https://doi.org/ 10.3892/etm.2018.6748.

Chingwaru, C., Bagar, T., Maroyi, A., Kapewangolo, P.T., Chingwaru, W., 2019. Wound healing potential of selected Southern African medicinal plants: a review. J. Herb. Med. 17-18, 100263. https://doi.org/10.1016/j.hermed.2019.100263.

Chithra, P., Sajithlal, G.B., Chandrakasan, G., 1998. Influence of Aloe vera on the healing of dermal wounds in diabetic rats. J. Ethnopharmacol. 59 (3), 195-201. https://doi:10.1016/s0378-8741(97)00124-4.

Crawford, A.D., Esguerra, C.V., De Witte, P.A.M., 2008. Fishing for drugs from nature: zebrafish as a technology platform for natural product discovery. Planta Med. 74, 624-632. https://doi.org/10.1055/s-2008-1034374, 06.

Deng, L.-J., Li, Y., Qi, M., Liu, J.-S., Wang, S., Hu, L.-H., Lei, Y.-H., Jiang, R.-W., Chen, W.-M., Qi, Q., Tian, H.-Y., Han, W.-L., Wu, B.-J., Chen, J.-X., Ye, W.-C., Zhang, D.-M., 2020. Molecular mechanisms of bufadienolides and their novel strategies for cancer treatment. Eur. J. Pharmacol. 887, 173379. https://doi.org/ 10.1016/j.ejphar.2020.173379.

Dreifke, M.B., Jayasuriya, A.A., Jayasuriya, A.C., 2015. Current wound healing procedures and potential care. Mater. Sci. Eng. C 48, 651-662. https://doi.org/ 10.1016/j.msec.2014.12.068.

Fan, T.-P., Yeh, J.-C., Leung, K.W., Yue, P.Y.K., Wong, R.N.S., 2006. Angiogenesis: from plants to blood vessels. Trends Pharmacol. Sci. 27 (6), 297-309. https://doi.org/ 10.1016/j.tips.2006.04.006.

Fuchs, S., Hsieh, L.T., Saarberg, W., Erdelmeier, C.A.J., Wichelhaus, T.A., Schaefer, L., Koch, E., Fürst, R., 2015. Haemanthus coccineus extract and its main bioactive component narciclasine display profound anti-inflammatory activities in vitro and in vivo. J. Cell Mol. Med. 19, 1021-1032. https://doi.org/10.1111/jcmm.12493. Epub 2015 Mar 5.

Gulluce, M., Sahin, F., Sokmen, M., Ozer, H., Daferera, D., Sokmen, A., Polissiou, M., Adiguzel, A., Ozkan, H., 2007. Antimicrobial and antioxidant properties of the essential oils and methanol extract from Mentha longifolia L. ssp. longifolia. Food Chem. 103, 1449-1456. https://doi.org/10.1016/j.foodchem.2006.10.061.

Ghuman, S., Coopoosamy, R., 2011. Crude sample preparation, extraction and in vitro screening for antimicrobial activity of selected wound healing medicinal plants in KwaZulu-Natal, South Africa: a review. J. Med. Plants Res. 5, 3572-3576.

Grierson, D.S., Afolayan, A.J., 1999. An ethnobotanical study of plants used for the treatment of wounds in the Eastern Cape, South Africa. J. Ethnopharmacol. 67, $327-332$. 
Heumann, D., Roger, T., 2002. Initial responses to endotoxins and Gram-negative bacteria. Clin. Chim. Acta 323 (1-2), 59-72. https://doi.org/10.1016/s0009-8981 (02)00180-8. Sep.

Houghton, P.J., Hylands, P.J., Mensah, A.Y., Hensel, A., Deters, A.M., 2005. In vitro tests and ethnopharmacological investigations: wound healing as an example. J. Ethnopharmacol. 100 (1-2), 100-107. https://doi.org/10.1016/j. jep.2005.07.001.

Huang, W., Yu, X., Liang, N., Ge, W., Kwok, H.F., Lau, C.B., Li, Y., Chung, H.Y., 2016. Anti-angiogenic activity and mechanism of sesquiterpene lactones from Centipeda minima. Nat. Prod. Commun. 11 (4), 435-438. https://doi.org/10.1177/ $1934578 \times 1601100402$.

Hutchings, A., 1996. Zulu Medicinal Plants: an Inventory. University of Natal Press.

Jansson, D., Dieriks, V.B., Rustenhoven, J., Leon, C.D., Smyth, L.C.D., Emma Scotter, E. Aalderink, M., Feng, S., Johnson, R., Schweder, P., Mee, E., Heppner, P., Turner, C., Curtis, M., Faull, R., Dragunow, M., 2021. Cardiac glycosides target barrier inflammation of the vasculature, meninges and choroid plexus. Commun. Biol. 4 (260) https://doi.org/10.1038/s42003-021-01787-x.

Joo, T., Sowndhararajan, K., Hong, S., Lee, J., Park, S.-Y., Kim, S., Jhoo, J.-W., 2014. Inhibition of nitric oxide production in LPS-stimulated RAW 264.7 cells by stem bark of Ulmus pumila L. Saudi J. Biol. Sci. 21 (5), 427-435. https://doi.org/10.1016/j. sjbs.2014.04.003.

Kasote, D., Ahmad, A., Viljoen, A., 2015. Chapter 6 - proangiogenic potential of medicinal plants in wound healing A2 - Mukherjee, pulok K. In: Evidence-Based Validation of Herbal Medicine. Elsevier, Boston, pp. 149-164.

Kasuya, A., Tokura, Y., 2014. Attempts to accelerate wound healing. J. Dermatol. Sci. 76 (3), 169-172. https://doi.org/10.1016/j.jdermsci.2014.11.001.

Katalinic, V., Milos, M., Kulisic, T., Jukic, M., 2006. Screening of 70 medicinal plant extracts for antioxidant capacity and total phenols. Food Chem. 94 (4), 550-557. https://doi.org/10.1016/j.foodchem.2004.12.004.

Kidd, K.R., Weinstein, B.M., 2003. Fishing for novel angiogenic therapies. Br. J. Pharmacol. 140 (4), 585-594. https://doi.org/10.1038/sj.bjp.0705496.

Küba, M.C., Türkoğlu, A., Oğuz, A., Tuncer, M.C., Kaya, Ş., Başol, Ö., Bilge, H., Tatlı, F., 2021. Comparison of local rosmarinic acid and topical dexpanthenol applications on wound healing in a rat experimental wound model. Folia Morphol. (Wroc.) 80 (3), 618-624. https://doi.org/10.5603/FM.a2020.0097.

Kumar, B., Vijayakumar, M., Govindarajan, R., Pushpangadan, P., 2007. Ethnopharmacological approaches to wound healing - exploring medicinal plants of India. J. Ethnopharmacol. 114 (2), 103-113. https://doi.org/10.1016/j. jep.2007.08.010.

Littleton, R.M., Hove, J.R., 2013. Zebrafish: a non-traditional model of traditional medicine. J. Ethnopharmacol. 145 (3), 677-685. https://doi.org/10.1016/j. jep.2012.11.003.

Liu, C.-L., Cheng, L., Kwok, H.-F., Ko, C.-H., Lau, T.-W., Koon, C.-M., Zhao, M., Lau, C.-P., Lau, K.-M., Wong, C.-W., Leung, P.-C., Fung, K.-P., Lau, C.B.-S., 2011. Bioassayguided isolation of norviburtinal from the root of Rehmannia glutinosa, exhibited angiogenesis effect in zebrafish embryo model. J. Ethnopharmacol. 137 (3), 1323-1327. https://doi.org/10.1016/j.jep.2011.07.060.

Liu, C.-L., Kwok, H.-F., Cheng, L., Ko, C.-H., Wong, C.-W., Ho, T.W.F., Leung, P.-C., Fung, K.-P., Lau, C.B.-S., 2014. Molecular mechanisms of angiogenesis effect of active sub-fraction from root of Rehmannia glutinosa by zebrafish sprout angiogenesis-guided fractionation. J. Ethnopharmacol. 151 (1), 565-575. https:// doi.org/10.1016/j.jep.2013.11.019.

Mabona, U., Van Vuuren, S.F., 2013. Southern African medicinal plants used to treat skin diseases. South Afr. J. Bot. 877, 175-193. https://doi.org/10.1016/j. sajb.2013.04.002.

Maes, J., Verlooy, L., Buenafe, O.E., De Witte, P.A.M., Esguerra, C.V., Crawford, A.D., 2012. Evaluation of 14 organic solvents and carriers for screening applications in zebrafish embryos and larvae. PLoS One 7, e43850.

Melguizo-Rodríguez, L., de Luna-Bertos, E., Ramos-Torrecillas, J., Illescas-Montesa, R., Costela-Ruiz, V.J., García-Martínez, O., 2021. Potential effects of phenolic compounds that can be found in olive oil on wound healing. Foods 10, 1642. https:// doi.org/10.3390/foods10071642.

Mensah, A.Y., Sampson, J., Houghton, P.J., Hylands, P.J., Westbrook, J., Dunn, M., Hughes, M.A., Cherry, G.W., 2001. Effects of Buddleja globosa leaf and its constituents relevant to wound healing. J. Ethnopharmacol. 77 (2-3), 219-226. https://doi.org/10.1016/S0378-8741(01)00297-5.

Metcalfe, A.D., Ferguson, M.W.J., 2007. Tissue engineering of replacement skin: the crossroads of biomaterials, wound healing, embryonic development, stem cells and regeneration. J. R. Soc. Interface 4 (14), 413-417. https://doi.org/10.1098/ rsif.2006.0179.

Mhlongo, F.N., 2017. Investigating the Wound Healing Properties of South African Medicinal Plants Using the Zebrafish Angiogenesis Assay. Masters dissertation. Tshwane University of Technology, South Africa.
Moghadam, S.E., Ebrahimi, S.N., Salehi, P., Farimani, M.M., Hamburger, M., Jabbarzadeh, E., 2017. Wound healing potential of chlorogenic acid and myricetin3-O- $\beta$-rhamnoside isolated from. Parrotia persica. Molecules 22, 1501. https://doi. org/10.3390/molecules22091501.

Moon, E.J., Lee, Y.M., Lee, O.H., Lee, M.J., Lee, S.K., Chung, M.H., Park, Y.I., Sung, C.K., Choi, J.S., Kim, K.W., 1999. A novel angiogenic factor derived from Aloe vera gel: beta-sitosterol, a plant sterol. Angiogenesis 3 (2), 117-123. https://doi.org/ 10.1023/a:1009058232389.

Park, S.H., Kim, D.S., Kim, S., Lorz, L.R., Choi, E., Lim, H.Y., Hossain, M.A., Jang, S., Choi, Y.I., Park, K.J., Yoon, K., Kim, J.-H., Cho, J.Y., 2019. Loliolide presents antiapoptosis and anti-scratching effects in human keratinocytes. Int. J. Mol. Sci. 20, 651. https://doi.org/10.3390/ijms20030651.

Percival, N.J., 2002. Classification of wounds and their management. Surgery 20 (5), 114-117.

Saha, K., Lajis, N.H., Israf, D.A., Hamzah, A.S., Khozirah, S., Khamis, S., Syahida, A., 2004. Evaluation of antioxidant and nitric oxide inhibitory activities of selected Malaysian medicinal plants. J. Ethnopharmacol. 92 (2-3), 263-267. https://doi.org/ 10.1016/j.jep.2004.03.007.

Schuermann, A., Helker, C.S.M., Herzog, W., 2014. Angiogenesis in zebrafish. Semin. Cell Dev. Biol. 31, 106-114. https://doi.org/10.1016/j.semcdb.2014.04.037.

Singab, A.-N.B., El-Hefnawy, H.M., Esmat, A., Gad, H.A., Nazeam, J.A., 2015. A systemic review on Aloe arborescens pharmacological profile: biological activities and pilot clinical trials. Phytother Res. 29, 1858-1867. https://doi.org/10.1002/ptr.5483.

Song, H.S., Park, T.W., Sohn, U.D., Shin, Y.K., Choi, B.C., Kim, C.J., Sim, S.S., 2008. The Effect of caffeic acid on wound healing in skin-incised mice. KOREAN J. PHYSIOL. PHARMACOL. 12 (6), 343-347. https://doi.org/10.4196/kjpp.2008.12.6.343.

Stadelmann, W.K., Digenis, A.G., Tobin, G.R., 1998. Physiology and healing dynamics of chronic cutaneous wounds. Am. J. Surg. 176 (2A Suppl. 1), 26S-38S. https://doi.org/ 10.1016/s0002-9610(98)00183-4.

Steyn, P.S., van Heerden, F.R., Vleggaar, R., Lourens, A.P., Anderson, L.A.P., 1999. Bufadienolide glycosides of the Crassulaceae. Structure and stereochemistry of orbicusides A-C, novel toxic metabolites of. Cotyledon orbiculate. J. Chem. Soc. Perkin Trans. 1 (24), 3537-3733. https://doi.org/10.1039/P19860001633.

Tabassum, N., Tai, H., Jung, D.-W., Williams, D.R., 2015. Fishing for nature's hits: establishment of the zebrafish as a model for screening antidiabetic natural products. Evid. Based Complement. Alternat. Med. 2015, 287847. https://doi.org/10.1155/ 2015/287847.

Tullberg-Reinert, H., Jundt, G., 1999. In situ measurement of collagen synthesis by human bone cells with a sirius red-based colorimetric microassay: effects of transforming growth factor beta2 and ascorbic acid 2-phosphate. Histochem. Cell Biol. 112 (4), 271-276. https://doi.org/10.1007/s004180050447.

Van Wyk, B.-E., Oudtshoorn, B.V., Gericke, N., 1997. Medicinal Plants of South Africa. Briza, South Africa.

Watt, J.M., Breyer-Brandwijk, M.G., 1962. The Medicinal and Poisonous Plants of Southern and Eastern Africa Being an Account of Their Medicinal and Other Uses, Chemical Composition, Pharmacological Effects and Toxicology in Man and Animal. Livingstone.

Weinstein, B.M., 2002. Plumbing the mysteries of vascular development using the zebrafish. Semin. Cell Dev. Biol. 13 (6), 515-522. https://doi.org/10.1016/ s1084952102001052.

Westerfield, M., 2000. The Zebrafish Book. A Guide for the Laboratory Use of Zebrafish (Danio rerio). Eugene: University of Oregon Press.

Yang, E.-J., Yim, E.-Y., Song, G., Kim, G.-O., Hyun, C.-G., 2009. Inhibition of nitric oxide production in lipopolysaccharide-activated RAW 264.7 macrophages by Jeju plant extracts. Interdiscipl. Toxicol. 2 (4), 245-249. https://doi.org/10.2478/v10102 009-0022-2.

Yang, D.J., Moh, S.H., Son, D.H., You, S., Kinyua, A.W., Ko, C.M., Song, M., Yeo, J., Choi, Y.-H., Ki Woo Kim, K.W., 2016. Gallic acid promotes wound healing in normal and hyperglucidic conditions. Molecules 21, 899. https://doi.org/10.3390/ molecules21070899.

Zheng, Y., Feng, Z., You, C., Jin, Y., Hu, X., Wang, X., Han, C., 2013. In vitro evaluation of Panax notoginseng Rg1 released from collagen/chitosan-gelatin microsphere scaffolds for angiogenesis. Biomed. Eng. Online 12, 134. https://doi.org/10.1186/1475-925X12-134.

Zhou, X., Siu, W.-S., Fung, C.-H., Cheng, L., Wong, C.-W., Zhang, C., Liu, C.-L., Kwok, H.F., Lau, C.-P., Wat, E., Lau, C.B.-S., Leung, P.-C., Ko, C.-H., Hung, L.-K., 2014. Proangiogenic effects of Carthami flos whole extract in human microvascular endothelial cells in vitro and in zebrafish in vivo. Phytomedicine 21 (11), 1256-1263. https://doi. org/10.1016/j.phymed.2014.06.010.

Zon, L.I., Peterson, R.T., 2005. In vivo drug discovery in the zebrafish. Nat. Rev. Drug Discov. 4 (1), 35-44. https://doi.org/10.1038/nrd1606.

Zuma, T., Wight, D., Rochat, T., Moshabela, M., 2016. The role of traditional health practitioners in rural KwaZulu-Natal, South Africa: generic or mode specific? BMC Compl. Alternative Med. 16 (1), 304. https://doi.org/10.1186/s12906-016-1293-8. 